\title{
Candidate SNPs for carcass and meat traits in Nelore animals and in their crosses with Bos taurus
}

\author{
Rogério Abdallah Curi(1), Monique Marcondes Krauskopf(1), Janaína Conte Hadlich ${ }^{(1)}$, \\ Marina Rufino Salinas Fortes ${ }^{(2)}$, Dianne Margaret Vankan ${ }^{(2)}$, Josineudson Augusto II Vasconcelos Silva(1), \\ Henrique Nunes de Oliveira ${ }^{(3)}$ and Marcílio Dias Silveira da Mota(1)
}

\begin{abstract}
(1)Universidade Estadual Paulista (Unesp), Faculdade de Medicina Veterinária e Zootecnia, CEP 18618-000 Botucatu, SP, Brazil. E-mail: rogcuri@fmvz.unesp.br, moniquekrauskopf@gmail.com, jana_hadlich@hotmail.com, jaugusto@fmvz.unesp.br, mdsmota@fmvz.unesp.br (2)The University of Queensland, School of Veterinary Science, St. Lucia, Queensland, 4072, Australia. E-mail: m.fortes@uq.edu.au, d.vankan@uq.edu.au (3)Unesp, Faculdade de Ciências Agrárias e Veterinárias, CEP 14884-900 Jaboticabal, SP, Brazil. E-mail: holiveira@fcav.unesp.br
\end{abstract}

\begin{abstract}
The objective of this work was to evaluate the effects of single-nucleotide polymorphisms (SNPs) in the genes IGF1 (AF_017143.1:g.198C > T), MSTN (AF_320998.1:g.433C >A), MYOD1 (NC_007313:g.1274A >G) and MYF5 (NC_007303:g.1911A >G) on carcass and meat traits in Nelore (Bos indicus) and Nelore $\mathrm{x}$ B. taurus. A total of 300 animals were genotyped and phenotyped for rib eye area (REA), backfat thickness (BT), intramuscular fat (IF), shear force (SF) and myofibrillar fragmentation index (MFI). The effects of allele substitution for each SNP were estimated by regression of the evaluated phenotypes on the number of copies of a particular allele using the general linear model. The polymorphism at $I G F 1$ was non-informative in Nelore animals. In crossbred animals, the IGF1 C allele was associated with greater REA. However, this relation was not significant after Bonferroni correction for multiple testing. The A allele of the MSTN polymorphism was absent in Nelore cattle and was only found in two crossbred animals. The polymorphisms of MYODI and MYF5 were little informative in Nelore animals with G allele frequency of 0.097 and A allele frequency of 0.031 , respectively. These markers show no association with the analyzed traits in the total sample of evaluated animals.
\end{abstract}

Index terms: Bos indicus, candidate gene, fat deposition, meat tenderness, polymorphism.

\section{SNPs candidatos para características da carcaça e da carne em Nelore e nos seus cruzamentos com Bos taurus}

\begin{abstract}
Resumo - O objetivo deste trabalho foi avaliar os efeitos de polimorfismo de nucleotídeo único (SNP) dos genes IGF1 (AF_017143.1:g.198C > T), MSTN (AF_320998.1:g.433C >A), MYOD1 (NC_007313:g.1274A>G) e MYF5 (NC_007303:g.1911A>G) nas características da carcaça e da carne em Nelore (Bos indicus) e Nelore $\mathrm{x}$ B. taurus. Trezentos animais foram genotipados e fenotipados para área de olho de lombo (REA), espessura de gordura na carcaça (BT), gordura intramuscular (IF), força de cisalhamento (SF) e índice de fragmentação miofibrilar (MFI). Os efeitos da substituição de alelos para cada SNP foram estimados por regressão dos fenótipos analisados sobre o número de cópias de um alelo em particular com uso de modelo linear geral. O polimorfismo do $I G F 1$ foi não informativo nos animais Nelore. Nos animais cruzados, o alelo C do $I G F 1$ foi associado à maior REA. No entanto, essa relação não se manteve significativa após a correção de Bonferroni para testes múltiplos. O alelo A do polimorfismo do MSTN mostrou-se ausente no gado Nelore e foi encontrado apenas em dois animais cruzados. Os polimorfismos do MYOD1 e do MYF5 foram pouco informativos nos animais Nelore com frequência do alelo $\mathrm{G}$ de 0,097 e do alelo A de 0,031, respectivamente. Esses marcadores não apresentam associações com as características analisadas na amostra total de animais avaliados.
\end{abstract}

Termos para indexação: Bos indicus, gene candidato, deposição de gordura, maciez da carne, polimorfismo.

\section{Introduction}

In beef cattle, variation in carcass composition and meat quality is observed within and between genetic groups, although the underlying mechanisms are not fully understood. Recent physiological and genomic studies have made progress in this area, revealing pathways and genes associated with carcass and meat traits. The genes insulin-like growth factor 1 (IGF1), myostatin (MSTN), myogenic differentiation 1

Pesq. agropec. bras., Brasília, v.47, n.2, p.294-301, fev. 2012 
(MYOD1) and myogenic factor 5 (MYF5) have been proposed as functional and positional candidate genes for carcass composition and meat quality in livestock (Ibeagha-Awemu et al., 2008; Bhuiyan et al., 2009).

Insulin-like growth factor-1 (IGF1), codified by the $I G F 1$ gene, has an essential role in regulating animal growth and metabolism (Hossner et al., 1997). IGF1 was mapped to chromosome 5, position $73.5 \mathrm{cM}$, and was located near quantitative trait loci (QTL) associated with fatness and other meat traits in beef cattle (Casas et al., 2000; Li et al., 2004a). Ge et al. (1997) identified a single-nucleotide polymorphism (SNP) in the regulatory region of $I G F 1$, located $512 \mathrm{pb}$ upstream of its first codon (AF_017143.1:g.198C $>$ T). This SNP was later associated to growth and carcass composition in Bos taurus and in B. taurus $\mathrm{x} B$. indicus crosses (Ge et al., 2001; Li et al., 2004b; Curi et al., 2005; Islam et al., 2009).

Analysis from a bovine QTL mapping study revealed a region with pleiotropic effects on a number of carcass and meat traits. The position of the detected QTL coincides with the mapped position of the MSTN gene on bovine chromosome 2 (Sellick et al., 2007). MSTN regulates skeletal muscle mass, and the SNP AF_320998.1:g.433C $>$ A (F94L) is a non-synonymous mutation identified in the coding region of the gene. Independent studies have indicated that F94L increases beef yield in $B$. taurus cattle carcasses without the disadvantages of double muscling effects (Alexander et al., 2007; Sellick et al., 2007; Esmailizadeh et al., 2008).

The MYODI and MYF5 genes of the MYOD family are potentially involved in muscle fiber development (Wyszyńska-Koko et al., 2006). MYOD1 was mapped to bovine chromosome 15 , between 37 and $40 \mathrm{cM}$, the same region in which a QTL for carcass and meat traits was found (Rexroad et al., 2001; Casas et al., 2003). The gene MYF5 was mapped to bovine chromosome 5 , between 0 and $30 \mathrm{cM}$ (more accurately at $19 \mathrm{cM}$ ), in the same region as a reported QTL for growth traits (Li et al., 2002). Bhuiyan et al. (2009) studied the effect of MYOD1 and MYF5 polymorphisms on growth and carcass traits in the Korean breed Hanwoo (B. taurus). These authors observed that two intronic polymorphisms, i.e., NC_007313:g.1274A $>$ G, a SNP in MYOD1, and NC_007303:g.1911A $>$ G, a SNP in $M Y F 5$, were significantly associated to live weight and carcass weight.
However, there is still a relative lack of information in the literature regarding the potential use of molecular markers for carcass and meat quality traits in B. indicus animals, especially of the Nelore breed, which are relevant for beef industries in Brazil.

The objective of this work was to evaluate the effects of SNPs in the genes IGF1 (AF_017143.1:g.198C $>$ T), MSTN(AF_320998.1:g.433C >A), MYOD1 (NC_007313: g.1274A $>\bar{G})$ and MYF5 (NC_007303:g.1911 $\overline{\mathrm{A}}>\mathrm{G})$ on carcass and meat traits in Nelore and in their crosses with $B$. taurus.

\section{Materials and Methods}

The experiment was done with 300 animals (32 females and 268 males), including 114 Nelore (B. indicus), 67 Angus x Nelore crosses (1/2 B. taurus $+1 / 2$ B. indicus), 44 Rubia Gallega $x$ Nelore crosses $(1 / 2$ B. taurus $+1 / 2$ B. indicus $), 41$ Canchim (5/8 $B$. taurus $+3 / 8$ B. indicus), 19 Brangus three-way crosses $(9 / 16$ B. taurus $+7 / 16$ B. indicus $)$ and 15 Braunvieh three-way crosses (3/4 B. taurus $+1 / 4$ B. indicus). The Rubia Gallega $\mathrm{x}$ Nelore crosses were made in a semi-intensive cattle-raising system in 2006. All other animals, from seven commercial herds, were bred in 2003, 2005, 2006 and 2007 using an intensive system, in the feedlot sector of the Department of Animal Nutrition and Genetic Breeding from the College of Veterinary Medicine and Zootechny of the Universidade Estadual Paulista (Unesp), Botucatu, SP, Brazil. All animals were bred according to the Brazilian legislation for animal well-being (protocol no. 89/2006) approved by the ethics committee on animal experimentation of the College of Veterinary Medicine and Zootechny of Unesp, Botucatu, SP, Brazil. The animals were slaughtered at 15, 17 and 19 months of age according to the guidelines for humane slaughter of cattle.

After slaughter, the identified carcasses were chilled for 24 hours before collecting two longissimus lumborum muscle samples ( $2.54 \mathrm{~cm}$ thick) between the $11^{\text {th }}$ and $13^{\text {th }}$ rib from the left-half carcasses.

Samples collected between the $12^{\text {th }}$ and $13^{\text {th }}$ rib were used to measure rib eye area (REA), backfat thickness (BT) and shear force (SF). Samples collected between the $11^{\text {th }}$ and $12^{\text {th }}$ rib were used to determine the myofibrillar fragmentation index (MFI) and intramuscular fat (IF or percentage of total lipids), as 
well as for the extraction of genomic DNA. REA was measured by the quadrant point method and BT by a ruler, both according to the methods described by the USDA Quality Grade (United States Department of Agriculture, 1997). After these first measurements at the slaughterhouse, the longissimus lumborum muscle samples were de-boned, vacuum-wrapped, aged at 1 to $2{ }^{\circ} \mathrm{C}$ for 14 days, and then frozen at $-20^{\circ} \mathrm{C}$. The other phenotypic measurements (SF, MFI and IF) were determined in the laboratory according to Wheeler et al. (1995), Culler et al. (1978) and Bligh \& Dyer (1959), respectively.

Genomic DNA was extracted from 250-mg meat samples by a non-phenolic method after digestion with proteinase $\mathrm{K}$ and precipitation with $\mathrm{NaCl}$ and alcohol. The IGF1, MYOD1 and MYF5 gene polymorphisms were genotyped by the polymerase chain reaction - restriction fragment length polymorphism (PCR-RFLP) method. The $\mathrm{C}$ and $\mathrm{T}$ alleles of the AF_017143.1:g.198C $>$ T SNP of $I G F 1$ were identified based on the amplification of a 249-bp fragment located in the regulatory region of the gene, followed by digestion with the restriction enzyme SnaBI (Ge et al., 2001). For identification of alleles $A$ and $\mathrm{G}$ of the NC_007313:g.1274A $>\mathrm{G}$ polymorphism of $M Y O D 1$, a fragment of 474 bp located in intron 1 was amplified and digested with Hinfl (Bhuiyan et al., 2009). Alleles A and G of the NC_007303:g.1911A $>$ G SNP, located in intron 2 of MYF5, were identified by the amplification of a 738-bp fragment followed by digestion with the restriction enzyme TaqI, as described by Bhuiyan et al. (2009). The amplified and digested DNA fragments of the IGFI and MYODI genes were separated on 3\% high-resolution agarose gels and of the MYF5 gene on 2\% agarose gels. A 100-bp molecular weight standard was included in each gel in order to calculate the size of the fragments produced. The genotypes of the individuals were determined for each polymorphism by analyzing the fragment size in base pairs. The $\mathrm{A}$ and $\mathrm{C}$ alleles of the AF_320998.1:g.433C $>$ A polymorphism, located in exon 1 of the MSTN gene, were identified using two real-time PCR assays (Vankan et al., 2010). In one of these assays, extracted DNA was amplified using real-time PCR, and post-amplification analysis was done by high-resolution melt (HRM) technology. The other assay was an allele-specific real-time PCR, which was used to confirm HRM results.
Allele and genotype frequencies were calculated for each polymorphism based on the identified genotypes. Differences in allele frequencies among and within the genetic groups were evaluated using contingency tables.

The allele substitution effects of the polymorphisms on the evaluated traits were estimated by regression of the analyzed phenotypes on the number of copies of a particular allele, using the general linear model (GLM) procedure of the SAS program (SAS Institute, 2004), as follows: $\mathrm{Y}_{\mathrm{ijk}}=\mu+\mathrm{CG}_{\mathrm{i}}+\mathrm{b} \times \mathrm{n}_{\mathrm{jk}}+\varepsilon_{\mathrm{ijk}}$, in which: $\mathrm{Y}_{\mathrm{ijk}}$ is the measured trait; $\mu$ is the overall mean; $\mathrm{CG}_{\mathrm{i}}$ is the fixed effect of the $i^{\text {th }}$ contemporary group $(i=1, \ldots, 13)$; $b$ is the regression coefficient; $n$ is the number of alleles of each polymorphism; and $\varepsilon_{\mathrm{ijk}}$ is the random error. For the IGF1, MYODI and MYF5 polymorphisms, regression was performed on the $\mathrm{T}, \mathrm{G}$ and $\mathrm{A}$ alleles, respectively. The contemporary groups considered animals of the same genetic group, sex, age at slaughter, feedlot year and farm of origin. It is important to note that these effects could not be considered separately in the model, since there is confounding among them. However, the sire effect was not included because the number of genotyped offspring from individual sires was very small. Therefore, due to the large number of parents, the possibility of confounding effects of allele and sire on the traits was minimized. To keep the error rate at 5\% probability, the Bonferroni correction for multiple comparisons was applied.

\section{Results and Discussion}

Genotype CC of the IGF1 SNP AF_017143.1: g. 198C $>$ T was identified by the presence of a single fragment of $249 \mathrm{bp}$. Genotype TT was characterized by two fragments of 226 and $23 \mathrm{bp}$, whereas heterozygotes (CT) showed three fragments $(249,226$ and $23 \mathrm{bp})$. Allele $\mathrm{C}$ was fixed among Nelore animals. In addition, the frequency of this allele was significantly higher than that of $\mathrm{T}$ in Angus $\mathrm{x}$ Nelore, Canchim, and in the Brangus three-way cross $(p<0.05)$. In Rubia Gallega $x$ Nelore and in the Braunvieh three-way cross there were no differences in allele frequencies $(p>0.05)$. When comparing genetic groups, the frequency of allele $\mathrm{C}$ was significantly higher in Nelore and Angus $\mathrm{x}$ Nelore than in Rubia Gallega x Nelore, Canchim, and in the Braunvieh three-way cross $(p<0.05)$. Brangus three-way cross cattle showed an intermediate 
frequency for allele $\mathrm{C}$ (Table 1). In studies with more than 20 breeds of cattle, including both dairy and beef cattle of $B$. taurus and $B$. indicus, the frequency of the $\mathrm{C}$ allele of $I G F 1$ ranged from 0.16 to 1.0 (Ge et al., 2001; Curi et al., 2005; Li et al., 2006; Islam et al., 2009). In B. taurus cattle, this SNP segregates - for example, in Angus, the frequency of the T allele was 0.64 (Ge et al., 2001) -, whereas in B. indicus, segregation was not observed. The frequency of the $\mathrm{C}$ allele in Nelore cattle was previously found to be 1.0 (Curi et al., 2005), which supports the results obtained in the present study. Therefore, these studies reinforce the hypothesis that the $\mathrm{T}$ allele could be a mutation only found in $B$. taurus breeds, since it occurred after the divergence between $B$. taurus and $B$. indicus.

Genotyping for the MSTN polymorphism AF_320998.1:g.433C $>$ A resulted in two heterozygous (AC) animals - a Rubia Galega x Nelore and a Canchim bull -, while all other were homozygous for the $\mathrm{C}$ allele. Normalized high-resolution melting curves were discriminated between $\mathrm{AC}$ and $\mathrm{CC}$ based on melt-curve shape and position. In allele-specific genotyping, homozygous $\mathrm{CC}$ genotypes showed a single-melting temperature peak, and heterozygous AC genotypes were identified by the presence of two peaks. Previous studies have shown that the mutant A allele of the MSTN SNP has high frequency in Limousin animals $(0.83)$ and that it was identified in Charolais, Blonde d'Aquitane and Angus cattle (Dunner et al., 2003; Sellick et al., 2007), which are all B. taurus. Vankan et al. (2009) analyzed the allele frequencies of this SNP in 1,140 individuals of 15 cattle breeds in Australia. The A allele

Table 1. Allele and genotype frequencies of the AF_017143.1:g.198C $>$ T SNP of the bovine IGF1 gene in the different genetic groups and in the total sample of animals ${ }^{(1)}$.

\begin{tabular}{lcccccc}
\hline Genetic group & \multicolumn{3}{c}{ Allele frequency } & \multicolumn{3}{c}{ Genotype frequency } \\
\cline { 2 - 3 } \cline { 6 - 7 } & $\mathrm{C}$ & $\mathrm{T}$ & & $\mathrm{CC}$ & $\mathrm{CT}$ & $\mathrm{TT}$ \\
\hline Nelore (114) & $1.000 \mathrm{Aa}$ & $0.000 \mathrm{Bb}$ & & 1.000 & 0.000 & 0.000 \\
Angus x Nelore (67) & $0.933 \mathrm{Aa}$ & $0.067 \mathrm{Bb}$ & & 0.866 & 0.134 & 0.000 \\
Rubia Gallega x Nelore (44) & $0.591 \mathrm{Ba}$ & $0.409 \mathrm{Aa}$ & & 0.182 & 0.818 & 0.000 \\
Canchim (41) & $0.646 \mathrm{Ba}$ & $0.354 \mathrm{Ab}$ & 0.439 & 0.415 & 0.146 \\
Brangus three-way cross (19) & $0.709 \mathrm{ABa}$ & $0.291 \mathrm{ABb}$ & 0.527 & 0.368 & 0.105 \\
Braunvieh three-way cross (15) & $0.533 \mathrm{Ba}$ & $0.467 \mathrm{Aa}$ & & 0.200 & 0.667 & 0.133 \\
\hline \multicolumn{2}{l}{ Total (300) } & 0.835 & 0.165 & 0.703 & 0.264 & 0.033 \\
\hline
\end{tabular}

${ }^{(1)}$ Frequencies followed by equal letters, uppercase in the columns and lowercase in the lines, do not differ at $5 \%$ probability. The number between parentheses indicates the number of animals in each genetic group. was present in Simmental (0.008), Piedmontese (0.02), Droughtmaster (0.04) and Limousin (0.942), but was not found in Salers, Angus, Poll Hereford, Hereford, Gelbvieh, Charolais, Jersey, Brahman (B. indicus), Holstein, Shorthorn or Maine Anjou. These results, which are in agreement with the present work, indicate the absence of polymorphism in $B$. indicus breeds and the absence or very low frequency of the A allele in most B. taurus breeds, except for Limousin.

Genotype AA of the MYOD1 polymorphism NC_007313:g.1274A $>$ G was identified by the presence of two restriction fragments of 319 and $155 \mathrm{bp}$. The heterozygous (AG) genotype had four fragments (319, 155,95 and $65 \mathrm{bp}$ ), while the homozygous (GG) one had three $(319,95$ and $65 \mathrm{bp})$. Within all evaluated groups, the frequency of the A allele was significantly higher than that of the $\mathrm{G}$ allele $(\mathrm{p}<0.05)$. Comparisons among groups indicated that the A allele had a higher frequency in Nelore cattle $(p<0.05)$, whereas no significant differences were observed among the other groups ( $>0.05)$ (Table 2$)$. The only known previous study of this MYODI polymorphism also reported higher frequencies of the A allele in $B$. indicus breeds: 0.69 in Brahman and 0.90 in Red Chittagong (Bhuiyan et al., 2009). In B. taurus breeds (Hanwoo, Angus, Simmental, Hereford and Shorthorn), the same authors found lower frequencies of the A allele, which ranged from 0.46 to 0.63 . These results are similar to those obtained in the present study, in which the A allele occurred with higher frequency in $B$. indicus (Nelore) than in the crossbreds (B. taurus $\times$ B $B$. indicus). This indicates a difference in the allele frequency of the

Table 2. Allele and genotype frequencies of the NC_007313:g.1274A $>$ G SNP of the bovine MYOD1 gene in the different genetic groups and in the total sample of animals ${ }^{(1)}$.

\begin{tabular}{|c|c|c|c|c|c|}
\hline \multirow[t]{2}{*}{ Genetic group } & \multicolumn{2}{|c|}{ Allele frequency } & \multicolumn{3}{|c|}{ Genotype frequency } \\
\hline & $\mathrm{A}$ & $\mathrm{G}$ & $\mathrm{AA}$ & $\mathrm{AG}$ & GG \\
\hline Nelore (114) & $0.903 \mathrm{Aa}$ & $0.097 \mathrm{Bb}$ & 0.825 & 0.158 & 0.017 \\
\hline Angus x Nelore (67) & $0.723 \mathrm{Ba}$ & $0.277 \mathrm{Ab}$ & 0.582 & 0.284 & 0.134 \\
\hline Rubia Gallega x Nelore (44) & $0.625 \mathrm{Ba}$ & $0.375 \mathrm{Ab}$ & 0.364 & 0.523 & 0.113 \\
\hline Canchim (41) & $0.683 \mathrm{Ba}$ & $0.317 \mathrm{Ab}$ & 0.536 & 0.293 & 0.171 \\
\hline Brangus three-way cross (19) & $0.684 \mathrm{Ba}$ & $0.316 \mathrm{Ab}$ & 0.474 & 0.421 & 0.105 \\
\hline Braunvieh three-way cross (15) & $0.633 \mathrm{Ba}$ & $0.367 \mathrm{Ab}$ & 0.467 & 0.333 & 0.200 \\
\hline Total (300) & 0.765 & 0.235 & 0.623 & 0.283 & 0.094 \\
\hline
\end{tabular}

${ }^{(1)}$ Frequencies followed by equal letters, uppercase in the columns and lowercase in the lines, do not differ at $5 \%$ probability. The number between parentheses indicates the number of animals in each genetic group. 
MYOD1 SNP between B. taurus and B. indicus. Allelic differences between $B$. taurus and $B$. indicus could reflect differences introduced through selection or simply genetic drift.

Genotype AA of the MYF5 polymorphism NC_007303:g.1911A $>$ G was identified by the presence of one fragment with $738 \mathrm{bp}$. The genotype GG showed two fragments (580 and $158 \mathrm{bp}$ ), whereas heterozygous (AG) genotypes showed three. Allele $G$ was more frequent than $A(p<0.05)$ within all but two groups: Brangus three-way cross and Braunvieh three-way cross. Among groups, allele $\mathrm{G}$ was more frequent in Nelore and Rubia Gallega x Nelore than in the other groups $(p<0.05)$ (Table 3$)$. Despite the small number of animals in some of the genetic groups and the lack of significant associations, a lower frequency of the A allele of the MYF5 SNP was observed in $B$. indicus (Nelore) cattle when compared to crossbreds (B. indicus $\times$ B. taurus). This result supports the notion that the A allele is more common in B. taurus cattle, a tendency previously observed by Bhuiyan et al. (2009), who found frequencies of the A allele ranging from 0.04 to 0.06 in B. indicus breeds (Brahman and Red Chittagong), and from 0.21 to 0.39 in B. taurus breeds (Hanwoo, Angus, Simmental, Hereford and Shorthorn).

The analysis of allele substitution effects (Table 4) showed no significant effects of the IGF1, MYODI and MYF5 polymorphisms on the traits of interest ( $>0.05)$.

Previous research on crossbreds (Simmental $\mathrm{x}$ Nelore, Angus x Nelore and Canchim, which are all

Table 3. Allele and genotype frequencies of the NC_007303:g.1911A $>$ G SNP of the bovine MYF5 gene in the different genetic groups and in the total sample of animals ${ }^{(1)}$.

\begin{tabular}{lcccccc}
\hline Genetic group & \multicolumn{3}{c}{ Allele frequency } & & \multicolumn{3}{c}{ Genotype frequency } \\
\cline { 2 - 3 } \cline { 5 - 7 } & $\mathrm{A}$ & $\mathrm{G}$ & & AA & AG & GG \\
\hline Nelore (114) & $0.031 \mathrm{Bb}$ & $0.969 \mathrm{Aa}$ & & 0.000 & 0.071 & 0.929 \\
Angus x Nelore (67) & $0.269 \mathrm{Ab}$ & $0.731 \mathrm{Ba}$ & & 0.000 & 0.537 & 0.463 \\
Rubia Gallega x Nelore (44) & $0.114 \mathrm{Bb}$ & $0.886 \mathrm{Aa}$ & 0.000 & 0.227 & 0.773 \\
Canchim (41) & $0.318 \mathrm{Ab}$ & $0.682 \mathrm{Ba}$ & 0.025 & 0.585 & 0.390 \\
Brangus three-way cross (19) & $0.395 \mathrm{Aa}$ & $0.605 \mathrm{Ba}$ & & 0.211 & 0.368 & 0.421 \\
Braunvieh three-way cross (15) & $0.467 \mathrm{Aa}$ & $0.533 \mathrm{Ba}$ & 0.133 & 0.667 & 0.200 \\
\hline Total (300) & 0.182 & 0.818 & 0.023 & 0.317 & 0.660 \\
\hline (1) Frequencies followed by equal letters, uppercase in the columns and \\
lowercase in the lines, do not differ at 5\% probability. The number between \\
parentheses indicates the number of animals in each genetic group.
\end{tabular}

B. taurus $\mathrm{x} B$. indicus crosses) indicated that the $\mathrm{C}$ allele of IGF1 is associated with heavier live weight and carcass weight, besides larger REA and BT scores (Curi et al., 2005). In the present work, the observed effect for the allele substitution of the IGF 1 SNP on REA ( $\mathrm{T}$ for $\mathrm{C}$ substitution represented an increase of $3.287 \mathrm{~cm}^{2}$ in REA; $p=0.0078$ ) was no longer significant $(\mathrm{p}=0.1173)$ after applying Bonferroni correction. Although non-significant (nominal p-value $=0.0888$; $\mathrm{p}$-value after adjustment by Bonferroni $=1$ ), the effect of the IGF1 SNP on backfat thickness (C allele increased BT by $0.342 \mathrm{~mm}$ ) occurred in the same direction as previously observed. In a recent study, Islam et al. (2009) analyzed this same IGF1 SNP in Angus, Charolais and hybrids (all B. taurus) and found significant associations for ultrasound backfat thickness, carcass average backfat and carcass lean meat yield (LMY) only in the Angus population, with genotype CC showing higher fat depth and lower LMY than genotype TT. Differences in the magnitude of the allele substitution effect can be attributed to differences in the cattle breed examined, in the linkage disequilibrium between populations (considering that the SNP might not be the casual mutation) and in epistasis. However, it is important to note that the direction of the effect was the same in all of the mentioned studies, with the $\mathrm{C}$ allele increasing rib eye

Table 4. Mean square (MS), F test (F), nominal p-values (p) and $\mathrm{p}$-values after adjustment by the Bonferroni method $(\mathrm{pB})$ for regression of the analyzed bovine traits in the number of alleles for each polymorphism.

\begin{tabular}{|c|c|c|c|c|c|}
\hline Polymorphism & Trait $^{(1)}$ & MS & $\mathrm{F}$ & $\mathrm{p}$ & $\mathrm{pB}$ \\
\hline IGF1 & $\operatorname{REA}\left(\mathrm{cm}^{2}\right)$ & 506.1483 & 7.1588 & 0.0078 & 0.1173 \\
\hline \multirow[t]{4}{*}{$($ AF_017143.1:g.198C $>$ T) } & BT (mm) & 5.4941 & 2.9148 & 0.0888 & 1 \\
\hline & IF $(\%)$ & 0.7829 & 1.0967 & 0.2958 & 1 \\
\hline & $\mathrm{SF}(\mathrm{kg})$ & 0.1424 & 0.2603 & 0.6102 & 1 \\
\hline & MFI & 278.3211 & 0.9762 & 0.3239 & 1 \\
\hline MYOD1 & $\operatorname{REA}\left(\mathrm{cm}^{2}\right)$ & 53.3543 & 0.7379 & 0.3909 & 1 \\
\hline \multirow{4}{*}{ (NC_007313:g.1274A $>$ G) } & BT (mm) & 1.2699 & 0.6685 & 0.4142 & 1 \\
\hline & IF $(\%)$ & 1.1831 & 1.6604 & 0.1985 & 1 \\
\hline & $\mathrm{SF}(\mathrm{kg})$ & 0.1746 & 0.3193 & 0.5724 & 1 \\
\hline & MFI & 331.8817 & 1.1649 & 0.2813 & 1 \\
\hline MYF5 & $\operatorname{REA}\left(\mathrm{cm}^{2}\right)$ & 14.1488 & 0.1953 & 0.6588 & 1 \\
\hline \multirow{4}{*}{ (NC_007303:g.1911A>G) } & BT (mm) & 3.7202 & 1.9672 & 0.1618 & 1 \\
\hline & IF $(\%)$ & 0.1729 & 0.2415 & 0.6234 & 1 \\
\hline & $\mathrm{SF}(\mathrm{kg})$ & 0.0739 & 0.1353 & 0.7132 & 1 \\
\hline & MFI & 3.8591 & 0.0135 & 0.9076 & 1 \\
\hline
\end{tabular}

(1)REA, rib eye area; BT, backfat thickness; IF, intramuscular fat; SF, shear force; MFI, myofibrillar fragmentation index. 
area and backfat thickness. This observation supports the notion that the $\mathrm{C}$ allele, which creates a putative binding site for a transcription factor (Islam et al., 2009), could be a functional mutation.

Recent studies have shown significant phenotypic effects associated with the F94L polymorphism of MSTN. Muscle mass was increased from 5.9 to $7.3 \%$ in heterozygous $\mathrm{AC}$ calves and from 12 to $15 \%$ in homozygous AA calves, with a reduction in carcass fat (Alexander et al., 2007; Sellick et al., 2007; Esmailizadeh et al., 2008). Unfortunately, the apparent non-existence of the A allele of the F94L SNP of the MSTN gene in pure breed Nelore and its very low frequency in only two of the other genetic groups imply that this SNP is inadequate for association studies in most Brazilian herds.

Another reason to investigate the associations between the MYOD1 SNP and the fatness (BT and IF) and tenderness (SF and MFI) traits was the reported existence of a QTL for meat tenderness and a percentage of kidney, heart and pelvic fat identified between 17 and $40 \mathrm{cM}$ of chromosome 15 (Rexroad et al., 2001; Casas et al., 2003). This QTL location coincides with the MYOD1 location. However, the reported lack of association does not support this gene as a candidate for the QTL. REA was the most likely trait to be associated with a MYOD1 SNP. Measurements of REA are correlated to meat yield, which is influenced by the number of muscle fibers formed during embryonic development, a process regulated by genes of the MYOD family (Olson, 1990). However, no association was found between REA and this MYODI SNP, which is in accordance with the lack of association observed in Korean Hanwoo cattle (B. taurus) (Bhuiyan et al., 2009).

Genes of the MYOD family have not been largely evaluated in cattle, but MYF5 is the most frequently reported in the literature. Other polymorphisms of MYF5 were associated with growth traits in Canadian commercial beef cattle (Li et al., 2004b), in Korean Hanwoo cattle (Chung \& Kim 2005; Bhuiyan et al., 2009) and in the Chinese cattle breed Qinchuan (Zhang et al., 2007), which are all B. taurus. The specific MYF5 SNP observed in the present study was initially described by Drogemuller \& Kempers (2000) and is located in the intron 2. The intron location indicates the possibility of direct and indirect effects of the SNP on phenotypes. This SNP of MYF5 was associated with average daily gain, and pre- and postweaning in B. taurus (Li et al., 2004b). In another study, the SNP was associated to live weight at 24 months of age, in Hanwoo cattle (B. taurus) (Bhuiyan et al., 2009). Hanwoo animals with AA genotype were heavier than those with GG and GA genotypes, and their carcass also tended to be heavier (Bhuiyan et al., 2009). However, no association was observed between this SNP in the intron 2 and the area of the muscle longissimus lumborum (Bhuiyan et al., 2009), as observed in the present work for REA in Nelore (B. indicus) and Nelore x $B$. taurus. The protein coded by MYF5 plays an important physiological role in myogenic lineage determination and myocyte differentiation (Braun et al., 1989). Consequently, associations of the MYF5 SNP with REA, SF and MFI could occur, but associations with BT and IF would not be expected. None of the QTL mapped close to MYF5 (Cattle QTL database, 2010) were related to fat deposition traits, such as BT or IF.

\section{Conclusions}

1. In Nelore, the fixation of $\mathrm{C}$ alleles in IGF1 (AF_017143.1:g.198C > T) and MSTN (AF_320998.1:g.433C >A), as well as the low frequency of the $\mathrm{G}$ allele in MYODI (NC_007313:g.1274A>G) and of the A allele in MYF5 (NC_007303:g.1911A $>\mathrm{G})$ make impossible or difficult the association studies between these markers and phenotypes.

2. There is no association between the IGF1 SNP and rib eye area in crossbred animals.

3. The evaluated SNPs of MSTN, MYOD1 and MYF5 are inadequate for marker-assisted selection in cattle with breed compositions similar to those evaluated.

\section{Acknowledgments}

To Fundação de Amparo à Pesquisa do Estado de São Paulo and to Conselho Nacional de Desenvolvimento Científico e Tecnológico, for financial support.

\section{References}

ALEXANDER, L.J.; GEARY, T.W.; SNELLING, W.M.; MACNEIL, M.D. Quantitative trait loci with additive effects on growth and carcass traits in a Wagyu-Limousin F2 population. Animal Genetics, v.38, p.413-416, 2007.

BHUIYAN, M.S.A.; KIM, N.K.; CHO, Y.M.; YOON, D.; KIM, K.S.; JEON, J.T.; LEE, J.H. Identification of SNPs in MYOD gene 
family and their associations with carcass traits in cattle. Livestock Production Science, v.126, p.292-297, 2009.

BLIGH, E.G.; DYER, W.J. A rapid method of total lipid extraction and purification. Canadian Journal of Biochemistry and Physiology, v.37, p.911-917, 1959.

BRAUN, T.; BUSCHHAUSEN-DENKER, G.; BOBER, E.; TANNICH, E.; ARNOLD, H.H. A novel human muscle factor related to but distinct from MyoD1 induces myogenic conversion in 10T1/2 fibroblasts. The EMBO Journal, v.8, p.701-709, 1989.

CASAS, E.; SHACKELFORD, S.D.; KEELE, J.W.; KOOHMARAIE, M.; SMITH, T.P.L.; STONE, R.T. Detection of quantitative trait loci for growth and carcass composition in cattle. Journal of Animal Science, v.81, p.2976-2983, 2003.

CASAS, E.; SHACKELFORD, S.D.; KEELE, J.W.; STONE, R.T.; KAPPES, S.M.; KOOHMARAIE, M. Quantitative trait loci affecting growth and carcass composition of cattle segregating alternative forms of myostatin. Journal of Animal Science, v.78, p.560-569, 2000.

CATTLE QTL DATABASE. Cattle Quantitative Trait Locus Database. Available at: <http:/www.animalgenome.org/cgi-bin/ QTLdb/BT/index>. Accessed on: 21 Oct. 2010.

CHUNG, E.R.; KIM, W.T. Association of SNP marker in $I G F-I$ and MYF5 candidate genes with growth traits in Korean cattle. Asian-Australasian Journal of Animal Science, v.18, p.1061-1065, 2005.

CULLER, R.D.; PARRISH JUNIOR, F.C.; SMITH, G.C.; CROSS, H.R. Relationship of myofibril fragmentation index to certain chemical, physical and sensory characteristics of bovine longissimus muscle. Journal of Food Science, v.43, p.1177-1180, 1978.

CURI, R.A.; OLIVEIRA, H.N. de; SILVEIRA, A.C.; LOPES, C.R. Association between $I G F-I, I G F-I R$ and GHRH gene polymorphisms and growth and carcass traits in beef cattle. Livestock Production Science, v.94, p.159-167, 2005.

DROGEMULLER, C.; KEMPERS, A. A TaqI PCR-RFLP at the bovine myogenic factor (MYF5) gene. Animal Genetics, v.31, p.146-147, 2000.

DUNNER, S.; MIRANDA, M.E.; AMIGUES, Y.; CANON, J.; GEORGES, M.; HANSET, R.; WILLIAMS, J.; MENISSIER, F. Haplotype diversity of the myostatin gene among beef cattle breeds. Genetics Selection Evolution, v.35, p.103-118, 2003.

ESMAILIZADEH, A.K.; BOTTEMA, C.D.; SELLICK, G.S.; VERBYLA, A.P.; MORRIS, C.A.; CULLEN, N.G.; PITCHFORD, W.S. Effects of the myostatin F94L substitution on beef traits. Journal of Animal Science, v.86, p.1038-1046, 2008.

GE, W.; DAVIS, M.E.; HINES, H.C. Two SSCP alleles identified in the 5'-flanking region of the bovine IGFI gene. Animal Genetics, v.28, p.155-156, 1997.

GE, W.; DAVIS, M.E.; HINES, H.C.; IRVIN, K.M.; SIMMEN, R.C.M. Association of genetic marker with blood serum insulin-like growth factor-I concentration and growth traits in Angus cattle. Journal of Animal Science, v.79, p.1757-1762, 2001.

HOSSNER, K.L.; MCCUSKER, R.H.; DODSON, M.V. Insulin-like growth factors and their binding proteins in domestic animals. Journal of Animal Science, v.64, p.1-15, 1997.
IBEAGHA-AWEMU, E.M.; KGWATALALA, P.; ZHAO, X. A critical analysis of production-associated DNA polymorphisms in the genes of cattle, goat, sheep, and pig. Mammalian Genome, v.19, p.591-617, 2008.

ISLAM, K.K.; VINSK, M.; CREWS, R.E.; OKINE, E.; MOORE, S.S.; CREWS JUNIOR, D.H.; LI, C. Association analyses of a SNP in the promoter of IGF1 with fat deposition and carcass merit traits in hybrid, Angus and Charolais beef cattle. Animal Genetics, v.40, p.766-769, 2009.

LI, C.; BASARAB, J.; SNELLING, W.M.; BENKEL, B.; KNEELAND, J.; MURDOCH, B.; HANSEN, C.; MOORE, S.S. Identification and fine mapping of quantitative trait loci for backfat on bovine chromosomes 2, 5, 6, 19, $21 \& 23$ in a commercial line of Bos taurus. Journal of Animal Science, v.82, p.967-972, 2004a.

LI, C.; BASARAB, J.; SNELLING, W.M.; BENKEL, B.; MURDOCH, B.; HANSEN, C.; MOORE, S.S. Assessment of positional candidate gene MYF5 and IGF1 for growth on bovine chromosome 5 in commercial lines of Bos taurus. Journal of Animal Science, v.82, p.1-7, 2004b.

LI, C.; BASARAB, J.; SNELLING, W.M.; BENKEL, B.; MURDOCH, B.; MOORE, S.S. The identification of common haplotypes on bovine chromosome 5 within commercial lines of Bos taurus and their associations with growth traits. Journal of Animal Science, v.80, p.1187-1194, 2002.

LI, M.H.; ADAMOWICZ, T.; SWITONSKI, M.; AMMOSOV, I.; IVANOVA, Z.; KISELYOVA, T.; POPOV, R.; KANTANEN, J. Analysis of population differentiation in North Eurasian cattle (Bos taurus) using single nucleotide polymorphisms in three genes associated with production traits. Animal Genetics, v.37, p.390-392, 2006.

OLSON, E.N. MYOD family: a paradigm for development? Genes and Development, v.4, p.1454-1461, 1990.

REXROAD III, C.E.; BENNETT, G.L.; STONE, R.T.; KEELE, J.W.; FAHRENKRUG, S.C.; FREKING, B.A.; KAPPES, S.M.; SMITH, T.P.L. Comparative mapping of BTA15 and HSA11 including a region containing a QTL for meat tenderness. Mammalian Genome, v.12, p.561-565, 2001.

SAS INSTITUTE. SAS/STAT: user's guide. Version 9.1. Cary: SAS Institute, 2004.

SELLICK, G.S.; PITCHFORD, W.S.; MORRIS, C.A.; CULLEN, N.G.; CRAWFORD, A.M.; RAADSMA, H.W.; BOTTEMA, C.D. Effect of myostatin F94L on carcass yield in cattle. Animal Genetics, v.38, p.440-446, 2007.

UNITED STATES DEPARTMENT OF AGRICULTURE. United States standards for grades of carcass beef. Washington: USDA, 1997. 18p.

VANKAN, D.M.; WAINE, D.R.; FORTES, M.R.S. Real-time PCR genotyping and frequency of the myostatin F94L mutation in beef cattle breeds. Animal, v.4, p.530-534, 2010.

WHEELER, T.L.; SHACKELFORD, S.D.; KOOHMARAIE, M. Shear force procedures for meat tenderness measurement. Clay Center: United States Department of Agriculture, 1995. 7p. 
WYSZYŃSKA-KOKO, J.; PIERZCHALA, M.; FLISIKOWSKI, K; KAMYCZEK, M.; RÓŻYCKI, M.; KURYŁ, J. Polymorphisms in coding and regulatory regions of the porcine MYF6 and MYOG genes and expression of the MYF6 gene in m. longissimus dorsi versus productive traits in pigs. Journal of Applied Genetics, v.47 p.131-138, 2006.
ZHANG, R.F.; CHEN, H.; LEI, C.Z.; ZHANG, C.L.; LAN, X.Y.; ZHANG, Y.D.; ZHANG, H.J.; BAO, B.; NIU, H.; WANG, X.Z. Association between polymorphisms of MSTN and MYF5 genes and growth traits in three Chinese cattle breeds. Asian-Australasian Journal of Animal Science, v.20, p.1798-1804, 2007.

Received on July 29, 2011 and accepted on January 27, 2012 